\title{
GENETIC SIGNATURE OF SOME HEMICHROMIS BIMACULATUS FISH POPULATIONS BASED ON MUSCLE PROTEIN POLYMORPHISM
}

\section{Mohamed, A. Rashed ${ }^{1}$; Ezzat A. Badawy ${ }^{2}$; Yasser M. Saad ${ }^{2}$ and Ashraf B. Abd EL-Rasek ${ }^{1}$}

1- Genetic Lab, National institute of oceanography and fisheries, Cairo- Egypt

2- Genetic Department, Faculty of agriculture, Ain Shams University, Cairo- Egypt

Key words: Genetic similarity, Isozyme, rotein polymorphism, Hemichromis bimaculatus, SDS-PAGE

\section{ABSTRACT}

Genetic signature of some Egyptian populations of the fish Hemichromis bimaculatus was detected using some isozyme systems including: Malate dehydrogenase (Mdh), Malic enzyme (ME), Esterase (Est) with three specific esterase substrates and protein polymorphisms. The applied samples were obtained from three distantly Egyptian locations namely, Qanater (Q population), Wadi EL-Rian (R population) and Lake Manzala (M1 and M2 populations). The samples were extracted froom skeletal muscles. Native PAGE (10\% polyacrylamide gel under non denaturing conditions) and SDS-PAGE were used to separate the saline soluble muscle proteins. The results indicated that each population had a unique banding pattern. The similarity was high within each population. The dendrogram indicated that (M1) and (M2) were much related to each other, while $(\mathrm{Q})$ population was distantly related to the other investigated populations.

\section{INTRODUCTION}

Several species of family Cichlidae have become popular for aquaculturists such as Tilapia sp. (Eknath, 1994), while H. bimaculatus is 
not popular because it has a small size, but its characters are useful for use as a model in laboratory tests especially in genetic studies.

Hemichromis bimaculatus (family: Cichlidae) is a small freshwater fish, with dark color on the upper side, pink to yellow on the lower and has sky blue dots on the head. The dorsal fin, anal fin and rays of the caudal fin are crimson. Its body cells have 44 chromosomes $(2 \mathrm{~N}=44)$ (Badawy, 2005).

About 160 fish species are endangered and about one species per year becomes extinct. The threats include water abstraction, pollution, overfishing and impacts of exotic species (Pullin, 199\%). Therefore, the need for establishing more criteria of species identification must be emphasized. The use of biochemical methods such as isozymes and protein electrophoretic techniques for species identification have been widely applied in fish (Ladewig and Shwantes, 1984; Bezrukov, 1987; Rashed et al.,1998; Saad et al., 2002). Some studies on muscle protein polymorphism concluded, that muscle protein was highly conserved which resulted in low intravariations (Rashed et al., 2000; Saad et al., 2002).

Analysis of electrophoretically detectable genetic variation is a useful mean of inferring the genetic structures of natural and farmed populations and for delineating taxonomic relationships (Hauser et al., 1998).

The present work aimed to study both intra and inter location genetic variations among the investigated fish populations, using proteinbanding pattern and Isozyme polymorphisms of saline soluble muscle proteins.

\section{MATERIAL AND METHODS}

The applied samples were collected from three distantly Egyptian locations namely: Qanater, Kalyobia (Q population), Lake Manzala, Dakahlia (M1 and M2 populations) and Lake Wadi EL-Rian, Fayoum (R population) .

Protein Extraction:

Skeletal Muscles were chosen for soluble protein extraction. The muscle samples $(0.25 \mathrm{~g}$ each) were powdered, using liquid nitrogen and extracted in appropriate volume of $0.85 \% \mathrm{NaCl}$ solution.

SDS-PAGE and Native PAGE electrophoresis:

For SDS PAGE, each sample $(100 \mu l)$ was diluted with an equal volume of $2 \mathrm{X}$ leans buffer (Laemmii, 1970) and samples extractions were 
GENETIC SIGNATURE OF SOME H. BIMACULATUS FISH 85 POPULATIONS BASED ON MUSCLE PROTEIN POLYMORPHISM

digested for $5 \mathrm{~min}$ (Saad et al., 2002). Samples were applied to $15 \%$ polyacrylamide gel. Gel preparation, electrophoresis conditions, staining and destaining gels were done according to Laemmli (1970).

For native gels, $10 \%$ polyacrylamide gel (under non denaturing conditions) with Tris-borate EDTA buffer pH8.6 (Markert and Faulhaber, 1965) was used to separate $30 \mu \mathrm{l}$ protein extract. All gels were stained according to Laemmli (1970).

Isozyme polymorphisms:

Muscle esterase isozyme polymorphisms:

The saline soluble skeletal muscles extracts were used for electrophoresis. Malate dehydrogenase (Mdh), Malic enzyme (ME), Esterase (Est) isozyme systems were used to study the population identity. Three synthetic esterase substrates namely: $\alpha$ naphthylpropionate, $\alpha$-naphthylacetate and $\alpha$-naphthylvalerate were employed to discriminate esterase isozyme variations (Tanksley and Rick, 1980; Tanksley and Orton, 1983 ; McAndrow and Majumdar, 1983)

Genetic similarity and distance:

Both genetic similarity and distance were estimated according to Bardacki and Skibinski (1994). Bands were scored as 1 if present or 0 if absent.

\section{Dendrogram Construction:}

SPSS package program was used to construct relationships among the examined fish populations.

\section{RESULTS}

SDS-PAGE and Native PAGE analysis of soluble muscle proteins:

The results led to the conclusion that muscle protein banding pattern had an importance in fish characterization. Accordingly, soluble fraction of muscle protein was considered in the present work to study population structure (inter-specific) of four $\mathrm{H}$. bimaculatus populations.

In the present work, two phases of study were conducted. Firstly, to assess the populations' structure (inter-specific) and secondly, to compare the populations (intra-specific) at both protein and Isozyme levels.

Inter- and intra-specific variations:

The SDS-PAGE protein patterns of the four examined populations are shown in Figs. 1-a, b, $c$ and $d$ for Q, M1, M2 and R populations, respectively. For comparison, each population was bulked and sampled (Fig. 1-e). 
The native PAGEs are shown in Figs. 2-a, b, $c$ and $d$ For comparison, each population was sampled by four individuals (Fig. 2-e).

The average similarity values (Table 1) and the total obtained bands (Table 2) within each population were calculated.

It is noticed from Table (1) that the total number of obtained bands were 24 SDS and 10 native, 23 SDS and 11 native, 23 SDS and 12 native and 26 SDS and 12 native for Q, M1, M2 and R populations respectively.

The average similarity values within each population was calculated based on SDS-PAGE and Native separated protein polymorphisms. They were $0.95,0.93,0.93$ and 0.97 for $\mathrm{Q}, \mathrm{M} 1, \mathrm{M} 2$ and $\mathrm{R}$ populations, respectively.

The similarity values among the four fish populations were presented in Table3 (down diagonal). They were $0.86,0.84,0.80,0.96$, 0.87 and 0.90 between $Q$ and $M 1, Q$ and $M 2, Q$ and $R, M 1$ and M2, M1 and $R$ and $M 2$ and $R$, respectively.

\section{Isozyme variations:}

The isozyme system patterns that include: Esterase (Est), Malate dehydrogenase (Mdh) and Malic enzyme (ME) are shown in Figs. (3-5)

The average values of similarity within each population were calculated based on each Isozyme system and summarized in Table (1). For comparison, four individuals from each population were dissected and sampled for Est. Isozyme system with two Est. isozymes, $\alpha$ naphthylpropionate and $\alpha$-naphthylacetate .

\section{Esterase (Est):}

The esterase Isozyme patterns are illustrated in Figs. 3a,b, c, d, e, $f, g, h, I, j, k$ and l.The estrases are a complex class of enzymes, where electrophoretic expression depends on the choice of substrate. With $\alpha$ naphthyl propionate, $\alpha$-naphthyl acetate and $\alpha$-naphthyl valerate synthetic as substrates, from seven to ten, from four to nine and from two to five anodally migrated Est bands (alleles) were respectively recognized in all populations.. All the examined samples shared some Est bands. High intense patterns were noted with $\alpha$-naphthyl propionate and $\alpha$-naphthyl acetate substrate.

Esterase with these two substrates was chosen to study the polymorphisms among the applied four populations (Figs. $3 \mathrm{~m}$ and $\mathrm{n}$ ). The similarity values among these four fish populations are presented in Table 3 (upper diagonal). They were $0.78,0.720 .640 .93,0.84$ and 0.91 
between $\mathrm{Q}$ and $\mathrm{M} 1, \mathrm{Q}$ and $\mathrm{M} 2, \mathrm{Q}$ and $\mathrm{R}, \mathrm{M} 1$ and $\mathrm{M} 2, \mathrm{M} 1$ and $\mathrm{R}$ and $\mathrm{M} 2$ and $R$, respectively.

The average values of similarity within each population were 1 , $0.88,1$ and 0.99 , using both $\alpha$-naphthyl propionate and $\alpha$-naphthyl acetate as Est. substrates for (Q), (M1), (M2) and (R) populations, respectively. On the other hand, the average values of similarities revealed from Est. with $\alpha$-naphthyl valerate were 0.89 and 0.80 for $(\mathrm{Q})$ and (M1) respectively, while it was 1 for both (M2) and (R) populations (Table 1).

\section{Malic Enzyme (ME):}

The Malic enzyme (ME) patterns are illustrated in Figs. (4a, b, c and d) for (Q), (M1), (M2) and (R) populations, respectively.

The total number of obtained (ME) bands are presented in Table ( 2 ). (R) population has three (ME) bands, while four bands were detected in the other populations (Q, M1 and M2).

The average values of similarity within each population was calculated. They were $0.99,0.93,0.83$ and 0.72 for $(\mathrm{Q}),(\mathrm{M} 1),(\mathrm{M} 2)$ and (R) populations, respectively.

Malate dehydrogenase (Mdh):

The Malate dehydrogenase (Mdh) patterns are illustrated in Figs. (5-a, b, c and d) for (Q), (M1), (M2) and (R) populations, respectively.

The total number of obtained (Mdh) bands are presented in Table (2). (R) population has two (Mdh) bands, while three bands were detected in the other populations $(\mathrm{Q}, \mathrm{M} 1$ and $\mathrm{M} 2)$.

\section{DISCUSSION}

\section{Protein polymorphisms:}

The obtained results showed that each population had a unique protein banding pattern. In addition, the same conclusion was revealed by different authors in other species of family Cichlidae such as $O$. niloticus (Rashed et al., 1998), S. gallilaeus and T. zillii (Falk et al., 1996), and O. aureus (Saad et al., 2002). On the other hand, in the catfish Claris gariepinus SDS-PAGE was a sensitive technique for studying fish population structures (Rashed et al., 2000)

Falk et al. (1996) separated water soluble skeletal muscle proteins of some species of family Cichlidae (S. gallilaeus and T. zillii) in a $5-30 \%$ polyacrylamide gradient gel. Each profile showed a high number of comassie stained proteins. In addition, the estimated MW of resolvable components ranged from $13-200 \mathrm{KDa}$. In another study carried out by 
Saad et al. (2002), SDS-PAGE was used to separate the skeletal muscle soluble protein extracts for detecting some biochemical markers of some Tilapia species. They found that, the similarity was high within each population. In addition, the estimated MW of resolvable components ranged from 13-206 $\mathrm{KDa}$.

The estimated MW of resolvable components in the present work ranged from $\approx 13-\approx 205 \mathrm{KDa}$. So, it can be concluded that in family Cichlidae, muscle proteins separating in the MW range from $\approx 13$ to $\approx 203$ $\mathrm{KDa}$. In addition, skeletal muscle soluble protein electrophoresis has a value in biochemical fingerprinting for fish populations and studying population structures.

Isozyme polymorphisms:

Among the three systems employed in the present study, the finest results were achieved with esterase banding profiles. The lowest Esterase (Est) resolution was revealed from Esterase with $\alpha$-naphthyl valerate, while the sharp and distinct banding and intense resolution were revealed from the other Esterase substrates ( $\alpha$-naphthyl propionate, $\alpha$-naphthyl acetate).

For the previous reasons, Esterase with these two substrates were chosen to study the polymorphisms among the applied four populations (Figs. $3 \mathrm{~m}$ and $\mathrm{n}$ ).

Bezrukov (1987) investigated the activity of five esterase isozyme in serum, liver and muscles in two stock populations of the grass carp Ctenopharyngodon idella. One polymorphic isozyme, designated Est-4, was found in liver and muscle tissues. The two carp stocks showed a significant difference in the frequencies of these alleles.

Comparable data were obtained by Rashed et al. (1998) for some Oreochromis niloticus populations including Acid phosphatase (Acph), Esterase (Est), Lactate dehydrogenase (Ldh), Malate dehydrogenase $(\mathrm{Mdh})$ and Superoxide dismutase (Sod) in different $O$. niloticus body organs. In order to trace reliable comparisons among some Oreochromis populations, the most reliable patterns were obtained in the case of Est isozymes in certain organs especially skeletal muscle Esterase with $\alpha$ naphthyl propionate. As reported by Cruze et al. (1982), ontogenic variations based on isozymes had a power for detecting genetic markers in Tilapias. Five esterase isozymes were detected in serum, liver and muscles of two stocks of the grass carp Ctenopharyngodon idella. In addition, one isozyme found in liver and muscles, designated Est-4, was polymorphic. 
GENETIC SIGNATURE OF SOME H. BIMACULATUS FISH 89 POPULATIONS BASED ON MUSCLE PROTEIN POLYMORPHISM

The wide tissues-distribution of esterase suggests that such enzyme may be housekeeping protein which serves as a general metabolic function characteristic of all cell types (Holmis and Whitt, 1970). The substerate tissue-specific differences in esterase spectera have been recorded, where the distribution of some esterase bands was varied in different organs and some of these bands were organ-specific.

In conclusion, our results suggested that, the genetic markers should be conducted to provide the information needed for a sound management of hatcheries, fish farming and wild stocks. Biochemical genetic markers would facilitate identification of fish species and allow for detection of species contamination. Isozyme variability has also been shown to be a good indicator of overall heterozygosity and can be used to assess the degree of inbreeding in a particular population.

The isozyme described in this study therefore provides a good basis for estimating the distribution of genetic variation within and between the applied Tilapia species. This conclusion agrees with those of Van der-Bank et al. (1989), Skaala et al. (1990), Rashed et al. (1998) Saad (2000) and Ramadan (2000)

Similar results were reported by Saad (2000) who discriminated some $O$. niloticus populations, using different esterase substrates, $\alpha$ naphthylbutyrate, $\alpha$-naphthylpropionate and $\alpha$-naphthylvalerate. The best and clear pattern was observed in case of $\alpha$-naphthyl propionate, while the worst was that of $\alpha$ naphthyl valerate. Based on the data given in esterase zymograms, $(\mathrm{Gi})$ and $(\mathrm{Wm})$ gave the best pattern compared to the other tissues. In the meantine, both muscle and gills esterase patterns had the value of fish population -substrate band specificity. The valerate derivative displayed often the fewer patterns.

The genetic distance revealed from the dendrogram construction (Fig. 6) reflects the geographical distance. From Fig. (6), (Q) population is more genetically and geographically distant from the other examined populations. On the other hand, (M1) and (M2) are closely related, and this is due to the small geographical distance between both of them. This indicated that there is relatively strong gene flow between both of them. Also the data showed that, $(R)$ population is more genetically distant from (M1) than (M2) population. Based on the geographical distance, both (M1) and (M2) were collected from Lake Manzala, but the first one was collected from east region while the second was collected from the west region of the Lake. 
Overall data showed that, the similarity values were high within each population. On the other hand, the similarity coefficient among the four populations of $H$.bimaculatus fluctuated between high (between $\mathrm{M} 1$ and M2) while the Lowest value was obtained between (Q) and (R).

The (R) population lives under special environmental conditions (Wadi EL-Rian), which has a brackish water area (the salinity in the upper Lake is 1.43 (Abd-Ella and Konsowa, 2002), while in the lower Lake is 5.6 (Konsowa and Abd-Ella 2002). The (R) population might be affected by these conditions that play a rode in natural selection for the salinity resistant fish individuals. On the other hand, the $(\mathrm{Q})$ population was collected from fresh water.

In conclusion, $H$. bimaculatus as a freshwater fish could live under different water conditions such as brackish water as Wadi EL-Rian or polluted water (Lake Manzala). This fish can be used as a model in genetic laboratory tests because it has specific characters such as small size and some stable morphological characterization (Badawy, 2005). In addition, it can be used as a source of salinity resistance genes, such as (R) population and pollutant resistance genes such as (M1) and (M2) populations:

\section{REFERENCES}

Abd-Ella, R., G. and Konsowa, A., H. (2002). Physicochemical characteristics and their effects on phytoplankton community in Wadi EL-Rian Lake, Egypt. upper Lake. J. Egypt. Acad. Soc. Environ. Develop., 3 (2): 1-27.

Badwy, E., A. Karyological study on Haplochromis bloyeti and Hemichromis bimaculatus.(2005). Egypt. J. Appl. Sci.,20 (10B).

Bardakci, F., and Skibinski, D. (1994). Application of the RAPD technique in tilapia fish: species and subspecies identification. Heredity, 73:177-123.

Bezrukov, V., F. (1987). Esterase isozymes and their variation in grass Carp T. Genet., 21:293-297. 
GENETIC SIGNATURE OF SOME H. BIMACULATUS FISH 91 POPULATIONS BASED ON MUSCLE PROTEIN POLYMORPHISM

Cruz, T.; Thorpc, J. and Pullin, R. (1982). Enzyme electrophoresis in Tilapia zillii: a pattern of determining biochemical genetic markers for use in tilapia stock identification. Aquaculture, 29:311-329.

Eknath, A., E. (1994). Managing aquatic genetic resources. Management example 4: The Nile Tilapia. International center for living Aquatic resources Management (ICLARM), MCP.O. Box 2631, Makati, Metro Manila 0718, Philippines.

Falk, T.; Abban, K; Obrest, S.; Villwo, W.; Pullin, V and Renwrantz, L. (1996). A biochemical Lab. Manual for species chracterization of some Tilapine fishes. ICLARM. Educ. Ser.17.93 R.

Hauser, G; Carvalho, R. and. Pitcher T., J. (1998): Genetic population structure in the Lake Tanganyika sardine Imnothrissa miodon. J. fish boil, 53:413-429.

Konsowa, A., H. and Abd-Ella, R., G. (2002). Physicochemical characteristics and their effects on phytoplankton community in Wadi EL-Rian Lake, Egypt. Lower Lake. J. Egypt. Acad. Soc. Environ. Develop., 3(2): 29-51.

Ladewig, P. and Schwantes, L. (1984). Loci that encode the lactate dehydrogenase in 23 species of fish belonging to the orders Cypriniformes, Siluriformes and Perciformes: Adaptative features. Comp. Biochem. Physiol. 77B (4):867-876.

Laemmli, U., k. (1970). Cleavage of structural proteins during the assembly of the head of bacteriophage T4. Nature, 227:680-258.

Markert, C. and Faulhaber, L. (1965). Lactate dehydrogenase isozyme patterns of fish. J. Exp. Zool. 159: 319-332.

Mc-Andrew B., J. and Majandar K.,C.(1983). Tilapia stock identification using electrophoretic markers. Aquaculture, 30: 249-261. 
Pullin, R., S. (1997). ICLARM. In Pullin RSV. Casal CMV, Abban EK and faek TM (eds). Characterization of Ghanian Tilapia genetic resources of use in fisheries and Aquacultur. ICLARM Conf. Proc. 52-58.

Ramadan, A., Abdel Rahman (2000). Genetic evolution of African Catfish (Calrias sp.) and Tilapia in Egypt. Ph.D. Thesis, Zagazig Univ., Egypt.

Rashed, M., A.; EL-Gamal, A., A.; Tantawi, T., M. and Saad, Y., M. (1998). Detection of Oreochromis niloticus lines by isozyme organs distribution and RAPD-PCR DNA markers. 3rd Arab Conference Modern Biotech. and Area of Application in the Arab world,14-17 Dec., Cairo, Egypt, pp.127-146.

Rashed M., A.;T. Tantawi, T., M; Atta, A.; Salah, Sherifa, H. and ELGamal, A., A. (2000).Plasma and muscle protein electrophoretic locality variations in catfish (Claris gariepinus L.). Egypt. J. gen. Cytol., 29 (2):127-146.

Saad, Y., M. (2000). Genetic fingerprint of some Oreochromis lines. MS.C. Thesis, Ain Shams Univ.. Egypt.

Saad, Y., M.; Rashed, M., A.; EL-Deep, I., Safaa; EL-Gamal, A., A. and Saiid., M., M. (2002). Molecular Genetic markers and phylogenetic relations for some Tilapia species. J. union Arab Biol. (Cairo), 17(A): 27-44.

Skaala, Q.; Dahle, G.; Jqrstad, E.and Naevdal, G. (1990). Interaction between natural and farmed fish populations: information from genetic markers. J. Fish Biol., 36: 449-460.

Taha, A. A. El-Mahmoudi, A., S. and El-Haddad, I., M. (2004). Pollution sources and related environmental impacts in the new 
GENETIC SIGNATURE OF SOME H. BIMACULATUS FISH 93 POPULATIONS BASED ON MUSCLE PROTEIN POLYMORPHISM

communities southeast Nile delta, Egypt. Emirates J. Engin. Res. $9(1): 35-49$.

Tanksley, D. and Rick, C. (1980). Genetics of esterases in species of Lycoporicon. Theor. Apple. Genetic., 56:209-219.

Tanksley, S. and Orton, T.(1983). Isozymes in plant genetic and breeding. Part (B). Elsevier Science Bublishers B.V. Amesterdam.

Van-der-Bank, F. H.; Grant, W. S. and Ferreira, J. T (1989). Electrophoretically detectable genetic data for fifteen South African Cichlids. J. Fish. Biol., 34:465-48 
Table (1): The average of similarity coefficient within each $H$. bimaculatus population based on biochemical marker polymorphisms.

\begin{tabular}{|l|l|l|l|l|}
\hline & \multicolumn{5}{|l|}{ H. bimaculatus populations } \\
\hline & $(\mathrm{Q})$ & $(\mathrm{M} 1)$ & $(\mathrm{M} 2)$ & $(\mathrm{R})$ \\
\hline Saline Soluble protein & 0.95 & 0.93 & 0.93 & 0.97 \\
\hline Est. $\alpha$-naphthylacetate & 1 & 0.88 & 1 & 0.99 \\
\hline Est $\alpha$-naphthylpropionate & 1 & 0.88 & 1 & 0.99 \\
\hline Est. $\alpha$-naphthylvalerate & 0.89 & 0.80 & 1 & 1 \\
\hline Mdh & 1 & 1 & 1 & 1 \\
\hline ME & 0.99 & 0.93 & 0.83 & 0.72 \\
\hline Average & 0.97 & 0.90 & 0.96 & 0.92 \\
\hline
\end{tabular}

$(\mathrm{Q})=$ Qanater, $(\mathrm{MI})=$ Manzala, $(\mathrm{M} 2)=$ Manzala and $(\mathrm{R})=$ Wadi EL-Rian

Table (2): The number of detected bands within each H.bimaculatus population based on biochemical marker polymorphisms.

\begin{tabular}{|l|l|l|l|l|}
\hline & \multicolumn{4}{|c|}{ H. bimaculatus populations } \\
\hline & $(\mathrm{Q})$ & $(\mathrm{M} 1)$ & $(\mathrm{M} 2)$ & $(\mathrm{R})$ \\
\hline SDS-PAGE & 24 & 23 & 23 & 26 \\
\hline Native & 10 & 11 & 11 & 12 \\
\hline Est. $\alpha$-naphthylacetate & 4 & 6 & 7 & 9 \\
\hline Est $\alpha$-naphthylpropionate & 7 & 8 & 9 & 10 \\
\hline Est. $\alpha$-naphthylvalerate & 5 & 5 & 4 & 2 \\
\hline Mdh & 3 & 3 & 3 & 2 \\
\hline ME & 4 & 4 & 4 & 3 \\
\hline
\end{tabular}

$(\mathrm{Q})=$ Qanater, $(\mathrm{Ml})=$ Manzala, $(\mathrm{M} 2)=$ Manzala and $(\mathrm{R})=$ Wadi EL-Rian

Table (3): Similarity coefficient among the four populations of H.bimaculatus based on soluble muscle proteins (down diagonal) and esterase isozyme (upper diagonal) polymorphisms.

\begin{tabular}{|l|l|l|l|l|}
\hline & $(\mathrm{Q})$ & $(\mathrm{M} 1)$ & $(\mathrm{M} 2)$ & $(\mathrm{R})$ \\
\hline$(\mathrm{Q})$ & & 0.78 & 0.72 & 0.64 \\
\hline$(\mathrm{M} 1)$ & 0.86 & & 0.93 & 0.84 \\
\hline$(\mathrm{M} 2)$ & 0.84 & 0.96 & & 0.91 \\
\hline$(\mathrm{R})$ & 0.80 & 0.87 & 0.90 & \\
\hline
\end{tabular}

$(\mathrm{Q})=$ Qanater, $(\mathrm{M} 1)=$ Manzala, $(\mathrm{M} 2)=$ Manzala and $(\mathrm{R})=$ Wadi EL-Rian 


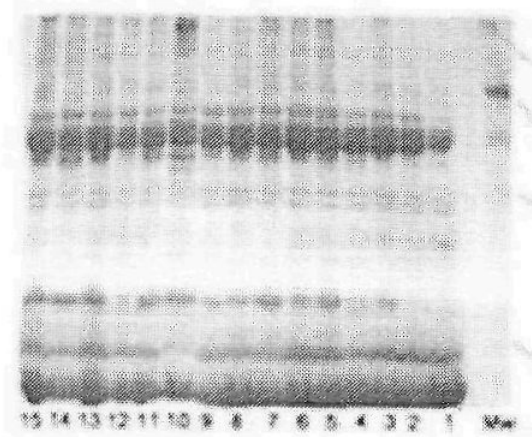

a

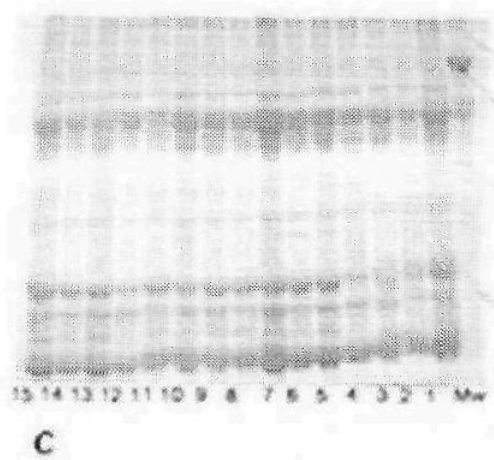

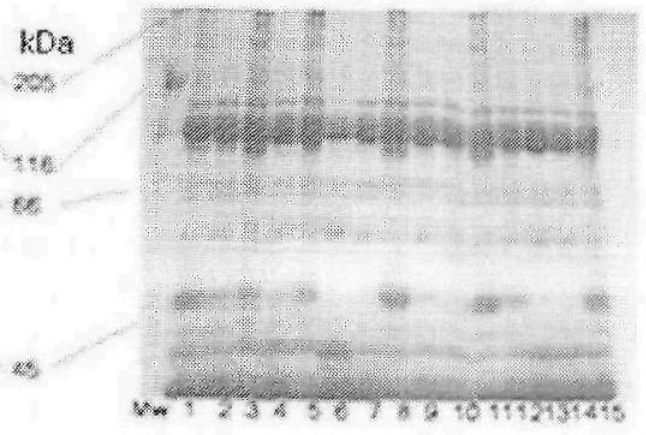

b

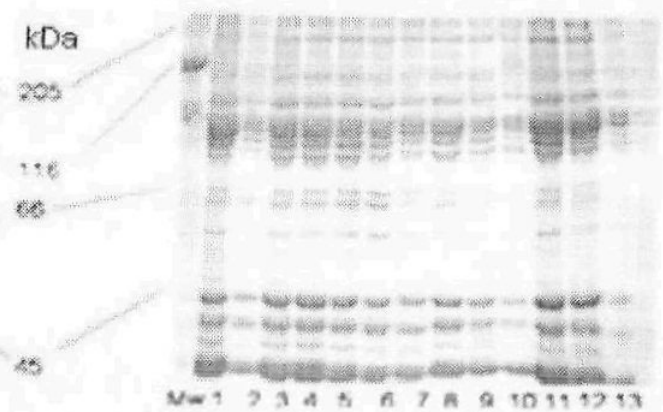

d

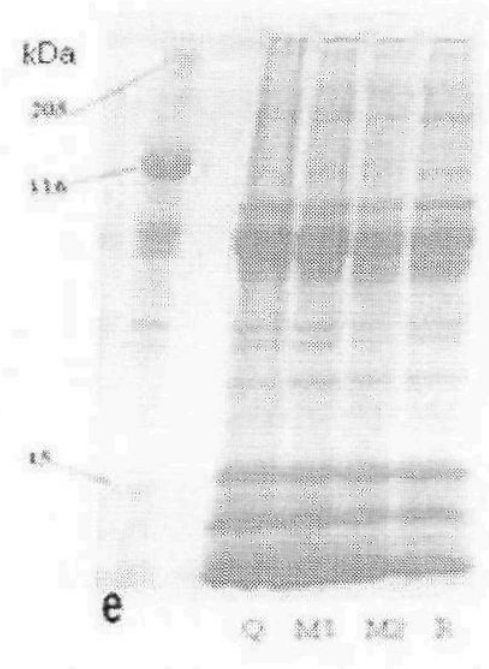

Figure (1): SDS-PAGE pattern of saline soluble Muscle protein polymorphisms of H.bimaculatus Populations $(\mathrm{a}=\mathrm{Q}, \mathrm{b}=\mathrm{M} 1, \mathrm{c}=\mathrm{M} 2, \mathrm{~d}=\mathrm{R}$ and $\mathrm{e}=$ bulked protein samples from each population) 

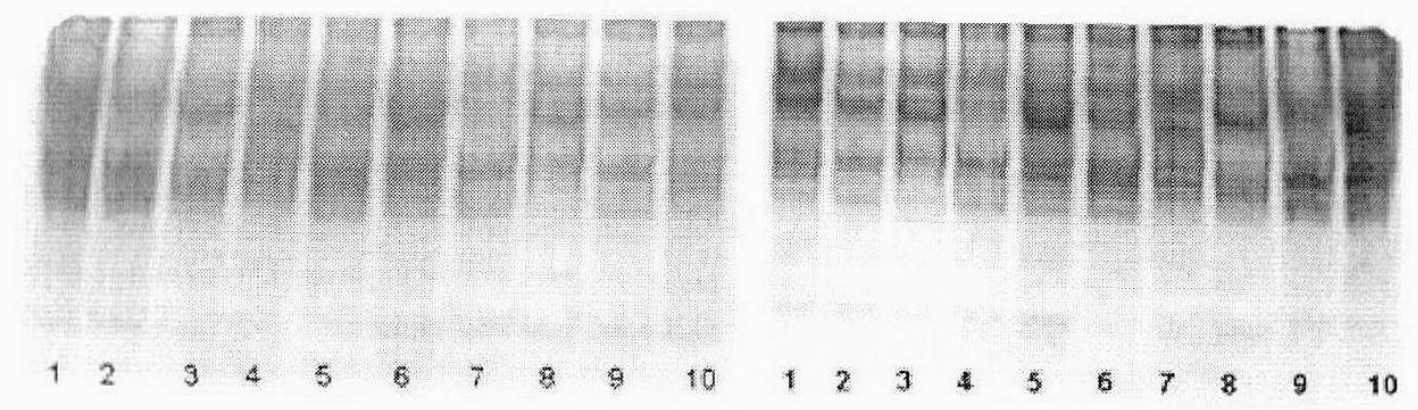

a

b
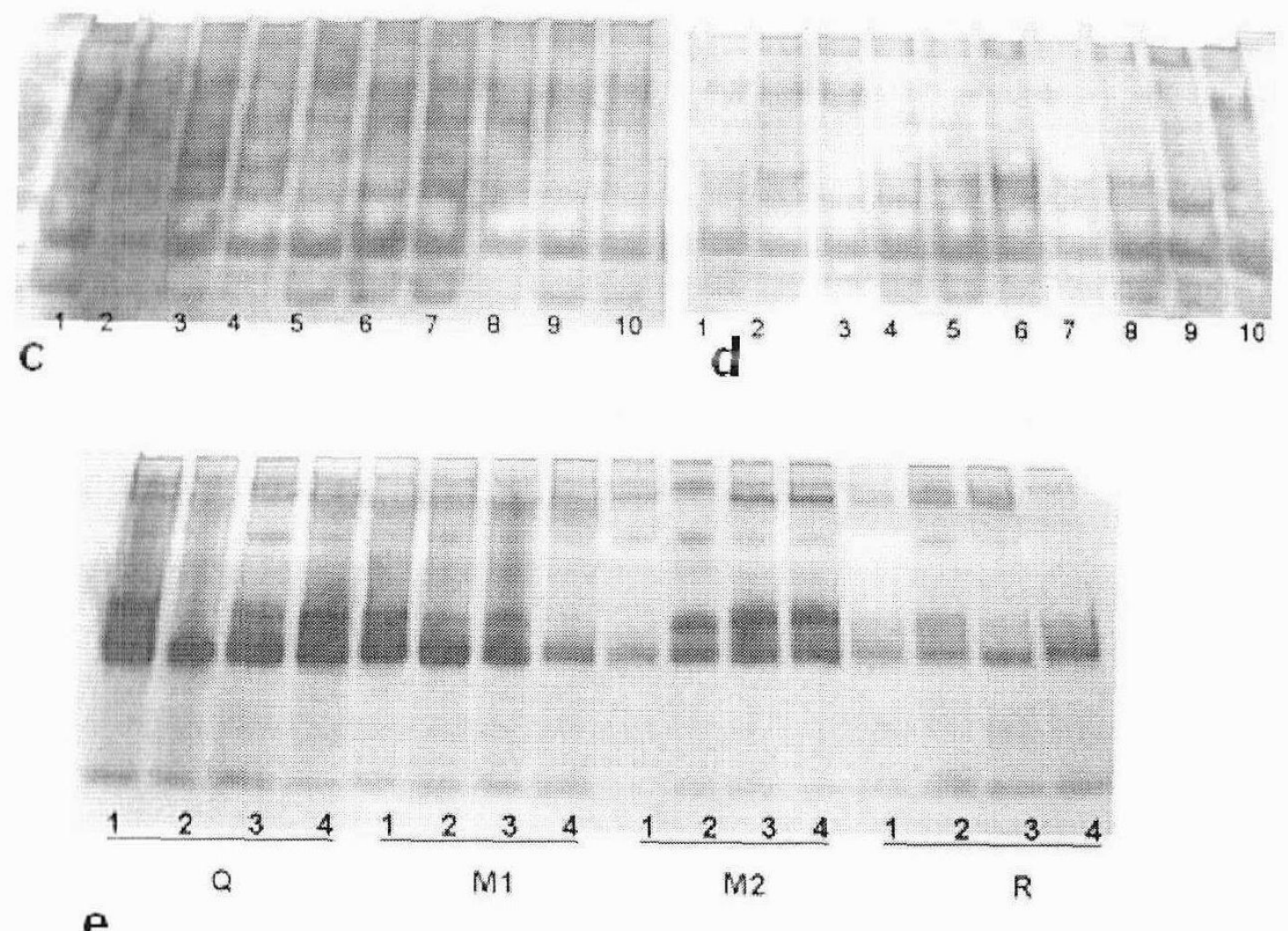

e

Figure (2): Native-PAGE pattern of saline soluble Muscle protein polymorphisms of H.bimaculatus Populations ( $\mathrm{a}=\mathrm{Q}, \mathrm{b}=\mathrm{M} 1, \mathrm{c}=\mathrm{M} 2, \mathrm{~d}=\mathrm{R}$ and $\mathrm{e}=$ four protein samples from each applied population) 


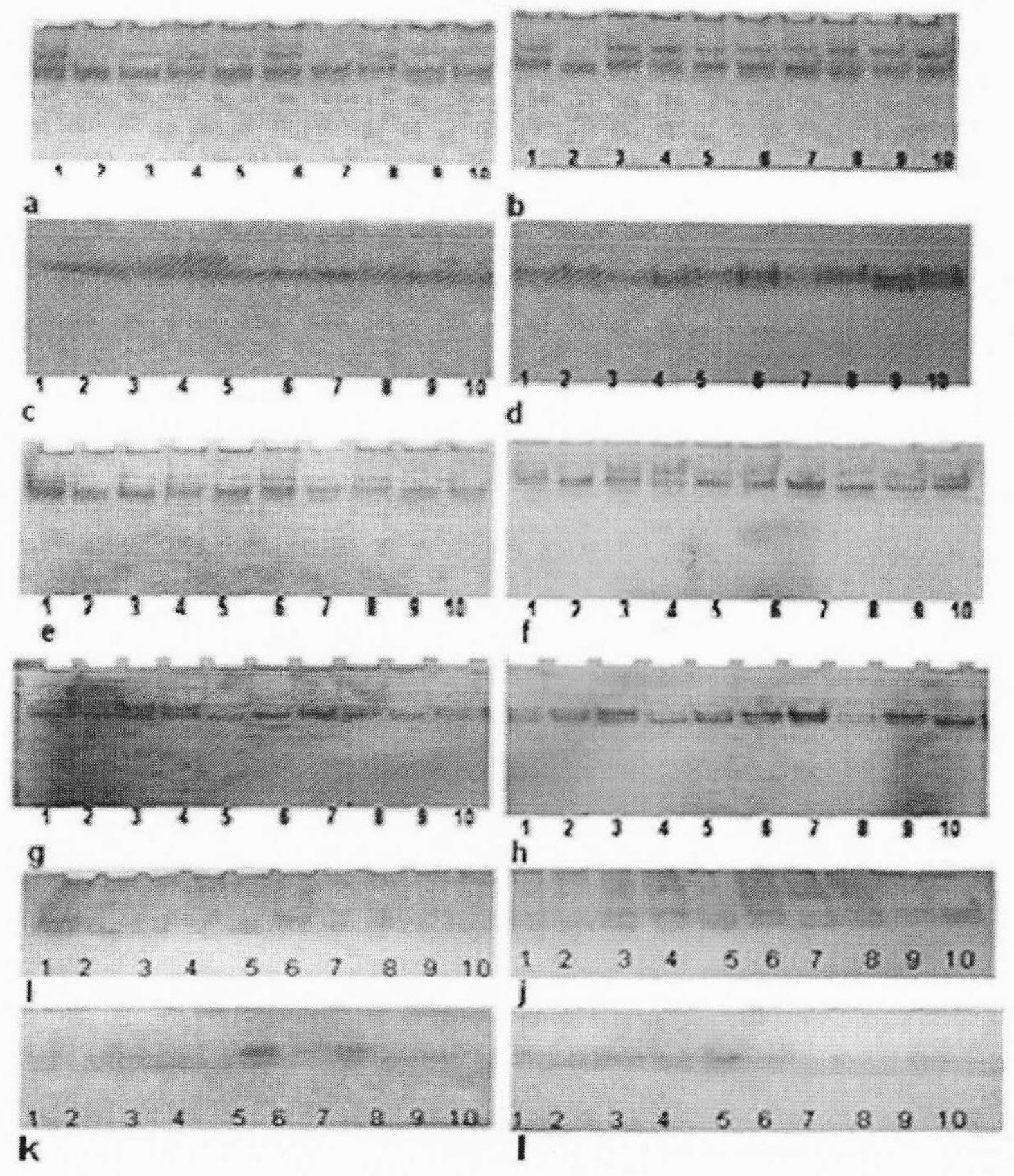

Figure (3): Electrophoretic pattern of esterase isozyme polymorphisms of H. bimaculatus populations generated by $\alpha$-naphthylpropionate $(\mathrm{a}, \mathrm{b}, \mathrm{c}$ and d), $\alpha$-naphthylacetate( $\mathrm{e}, \mathrm{f}, \mathrm{g}$ and $\mathrm{h}$ ) and $\alpha$ - naphthylvalerate $(\mathrm{I}, \mathrm{j}, \mathrm{k}$ and $\mathrm{l})$, 


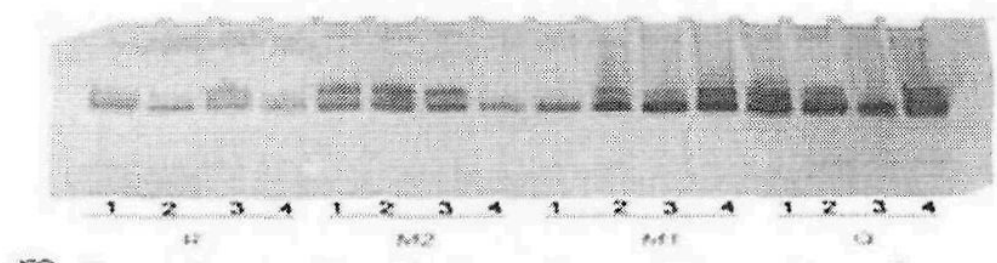

m

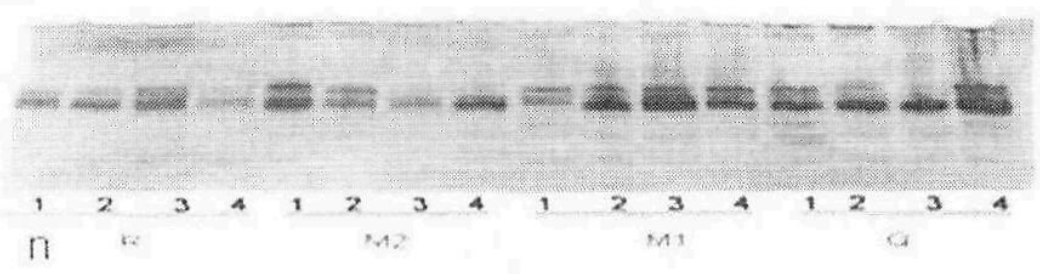

Figure (3-m and $\mathbf{n})$ : Electrophoretic pattern of esterase isozyme polymorphisms of $H$. bimaculatus populations generated by $\alpha$ - naphthylpropionate (m) and $\alpha$ naphthylacetate $(\mathrm{n}),(\mathrm{Q})=$ Qanater, $(\mathrm{M})=$ Manzala and $(\mathrm{R})=$ Wadi EL-Rian
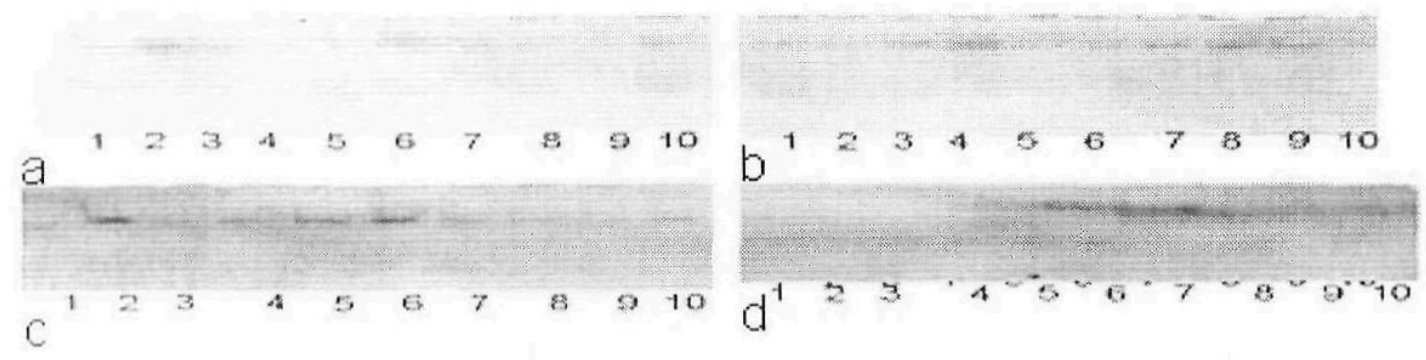

Figure(4-a, b, c and d3): Electrophoretic pattern of ME isozyme polymorphisms of $H$. bimaculatus populations $(\mathrm{a}=\mathrm{Q}, \mathrm{b}=\mathrm{M} 1, \mathrm{c}=\mathrm{M} 2, \mathrm{~d}=\mathrm{R}$ )
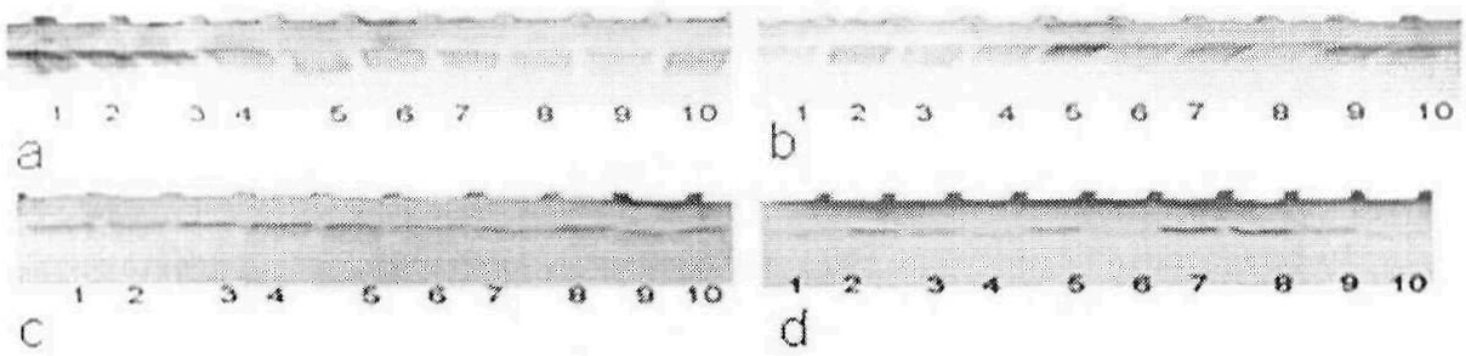

Figure(5-a, b, c and d3): Electrophoretic pattern of ME isozyme polymorphisms of H.bimaculatus populations $(\mathrm{a}=\mathrm{Q}, \mathrm{b}=\mathrm{M} 1, \mathrm{c}=\mathrm{M} 2, \mathrm{~d}=\mathrm{R})$ 
GENETIC SIGNATURE OF SOME H. BIMACULATUS FISH 99 POPULATIONS BASED ON MUSCLE PROTEIN POLYMORPHISM

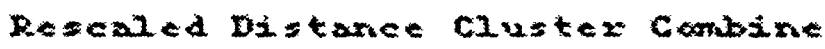

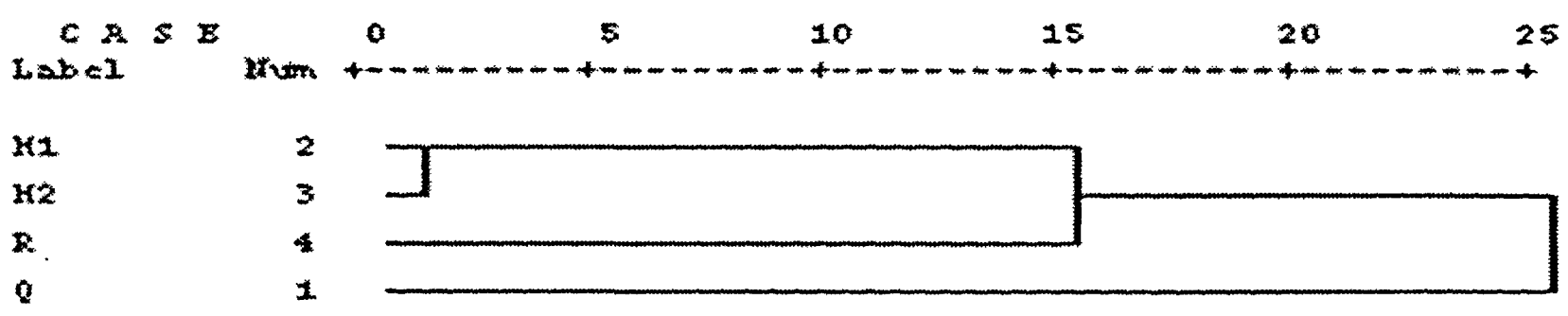

Figure (6): Dendrogram of genetic relationship among the four applied populations. (Q) = Qanater, (M1)=Manzala, (M2)=Manzala and $(\mathrm{R})=$ Wadi EL Rian 